Campbell, M. (1949). Quart. F. Med., 18, 379.

(1955). Brit. Heart 9., 17, 511.

1959). Ibid., 21, 65.

1961a). Brit. med j., 1, 691

1961b). Acta Genet med. (Roma), 10, 443.

1962). Brit. Heart \%., 24, 625

1962). Brit. Heart f., 24.

(1966). In A Textbook of Paediatric Cardiology, edited by Hamish

Watson. Lloyd-Luke, Lundon. In preparation.

and Baylis, J. H. (1956). Brit. Heart f., 18, 475

and Goodwin, J. F. (1965). Progr. cardiovasc. Dis., 7, 417

and Polani, P. E. (1961a). Lancet, 1, 463.

- (1961b). Brit. Heart f., 23, 477.

Carlgren, L.-E. (1959). Ibid., 21, 40.

Carter, C. O. (1961). In Conference on Clinical Aspects of Genetics $(1961)$, p. 30

Cockayne, E. A. (1938). Quart. F. Med., 7, 479.

Conference on Clinical Aspects of Genetics held at the Royal College of Physicians of London (1961). Pitman Medical Publishing Co., Ltd., London. Edited by F. A. Jones.

Conte, W. R., McCammon, C. S., and Christie, A. (1945). Amer. F. Dis. Child., 70, 301 .

Cox, Diane W. (1964). Amer. F. hum. Genet., 16, 214.

Edwards, J. H. (1958). Brit. f. prev. soc. Med., 12, 115

Evans, W. (1947). Brit Heart $\mathcal{F}_{\text {., }} 11,68$.

First International Conference on Congenital Malformations, London 18-22 July 1960. Lippincott, Philadelphia and Montreal, 1961, and Pitman, London, 1962.

Ford, E. B., and Huxley, J. S. (1927). Brit. F. exp. Biol., 5, 112

Foxon, G. E. H. (1959) Brtt. Heart 7., 21, 51.

Fraser, F. C. (1959). F. chron. Dis., 10, 97

Fuhrmann, W. (1958). Z. menshl. Vererb.-u Konstit.-Lehre, 34, 563. (1961). Acta genet. (Basel), 11, 289.

Gibson, S., and Lewis, K. C. (1952). Amer. F. Dis. Child., 83, 317.

Harris, L. E., and Steinberg, A. G. (1954). Pediatrics, 14, 314.

Ingalls, T. H., Avis. F. R., Curley, F. J., and Temin, H. M. (1953). ₹. Hered., 44, 185.

Kalter, H.'(1954a). Genetics, 39, 185.

(1954b). Ibid., 39, 975 .

- and Warkany, J. (1957). 7. exp. Zool., 136, 531.

Keith, J. D., Rowe, R. D., and Vlad, P. (1958). Heart Disease in Infancy and Childhood. MacMillan, New York.

Lamy, M., de Grouchy, J., and Schweisguth, O. (1957). Amer. F. hum. Genet., 9, 17

Landauer, W. (1945). 7. exp. Zool., 98, 1.

- (1947). Ibid., 105, 145 .

(1952). Ibid., 120, 469.

- (1953). Genetics, 38, 216.

Lerner, I. M. (1954). Genetic Homeostasis. Oliver and Boyd, Edinburgh and London.

Lynas, M. A. (1958). Ann. hum. Genet., 22, 289.

MacArthur, P. (1952). Lancet, 2, 1104

McIntosh, R., Merritt, K. K., Richards, M. R., Samuels, M. H., and Bellows, M. T. (1954). Pediatrics, 14, 505.
McKeown T., MacMahon, B., and Parsons, C. G. (1953). Brit. Heart 7., 15,273 .

- and Record, R. G. (1951). Lancet, 1, 192.

- (1960). In Ciba Foundation Symposium on Congenital Malformations, edited by G. E. W. Wolstenholme and C. M. O'Connor, p. 5. Churchill, London.

MacMahon, B. (1952). Brit. F. soc. Med., 6, 178.

- Mckeown, T., and Record, R. G. (1953). Brit. Heart 7., 15, 121

Mouquin, M., Kherimian, R., Durand, M., Metianu, C., Moullec, J., and Kherumian-Allary, O. (1956). Bull. Acad. nat. Méd. (Paris), 140, 515.

Neel, J. V. (1960). In First International Conference on Congenital Malformations, p. 63

Paré, J. A. P., Fraser. R. G., Pirozynski, W. J., Shanks, J. A., and Stubington, D. (1961). Amer. F. Med., 31, 37.

Penrose, L. S. (1955;. Lancet, 2, 312

- (1957) Amer. 7 hum. Genet. 9, 167.

Polan, P. E., and Campbell, M. (1955). Ann. hum. Genet., 19, 209.

Record, (1960). Ibid., 24, 343.

Record, R. G. and Edwards, J. H. (1958). Brit. F. prev. soc. Med., 12, 8. Registrar-General and 1957 . (1953). Brit. Heart f., 15, 376.

Registrar-General (1957). Statistical Review of England and Wales for 1957. Part I1, Tables, Civil, Table L. H.M.S.O., London.

Rhodes, A J. (1960). In First International Conference on Congenital Malformations, p 106.

Roberts, J. A. F. (1953-5). Med. 7. South-West, 70, 142.

Rutstein, D. D., Nickerson, R. J., and Heald, F. P. (1952). Amer. F. Dis. Chila., 84, 199

Seldon, W. A., Rubinstein, C., and Fraser, A. A. (1962). Brit. Heart f. 24. 557.

Siller, W G. (1958). 7. Path. Bact., 76, 431.

Sorsby, A. (1953). Clinical Genetics. Butterworth, London.

Stevenson. A C. (1957). Amer. 7. hum. Genet., 9, 81.

Taylor, A. I., and Polani, P. E. (1964). Guy's Hosp. Rep., 113, 231.

Tihen, J A., Charles, D. R., and Sippel, T. O. (1948). F. Hered., 39,29

Torgersen. J. (1946). Acta med. scand., 126, 319.

Tr (1950). Amer. F. hum. Genet., 2, 361.

Trasler. D. G. (1958). Genetics and other factors influencing the pathogenesis of cleft-palate in mice. Ph.D. thesis, McGill Univ., Montreal. Quoted by Furhmann (1962).

Uchida, Irene A., and Rowe, R. D. (1957). Amer. 3. hum. Genet., 9 133

Warkany, J. (1960). In First International Conference on Congenital Malformations, p. 99

Weil. M. H., and Ȧllenstein, B. J. (1961). New Engl. 3. Med., 265, 661. Wilson. J. G. (1959). F. chron. Dis., 10, 111. (1960). In First International Conference on Congenital Malformations, p. 187.

Roth. C. B., and Warkany, J. (1953). Amer. F. Anat., 92, 189.

- and Warkany, J. (1949). Ibid.. 85, 113.

Wood. P. (1956). Diseases of the Heart and Circulation, 2nd ed. Eyre and Snottiswoode, London.

Zoethout, H. E., Bonham Carter, R. E., and Carter, C. O. (1964). F. med. Genet., 1, 2 .

\title{
Value of Ampicillin in the Hospital Treatment of Exacerbations of Chronic Bronchitis
}

\author{
P. C. ELMES,* M.D., M.R.C.P. ; T. K. C. KING,* M.D., M.R.C.P. ; \\ JEAN H. M. LANGLANDS,* M.D., M.R.C.P.ED. ; J. A. MACKAY,* M.D. ; \\ W. F. M. WALLACE,* M.B., B.CH., B.SC. ; O. L. WADE,* M.D., F.R,C.P. ; \\ T. S. WILSON, $†$ M.B., B.CH., M.R.C.P.I.
}

Brit. med. F., 1965, 2, 904-908

Authoritative teaching on the management of chronic bronchitis stresses the importance of giving antibacterial agents for acute exacerbations (Crofton, 1963 ; Garrod, Scadding, and Watson, 1963). But Johnston (1963) reviewed the clinical evidence of the nine controlled clinical trials of treatment of exacerbations of bronchitis which had been carried out up to that time and found that definite evidence of benefit was shown in only one trial. In his opinion the evidence in favour of the long-term prophylactic use of antibiotics was more definite than that in favour of the therapeutic use for acute illnesses.

\footnotetext{
* Department of Therapeutics and Pharmacology, Queen's University,

Belfast.
+ Central Laboratories at the Belfast City Hospital.
}

The pathogenic organisms which are considered important (May, 1958) are Haemophilus influenzae and Streptococcus pneumoniae. These are often found in the sputum during acute exacerbations, and the sputum usually becomes purulent (Elmes and White, 1953). There is histological evidence (Lynne Reid, 1958) that bacterial invasion during acute exacerbations causes the permanent damage to the lung. However, antibiotics given between exacerbations produce no immediate benefit even when the sputum is purulent, although the same "pathogenic" bacteria are often found in the sputum (Elmes, Knox, and Fletcher, 1953).

The routine use of antibiotics in the management of patients with acute exacerbations of bronchitis admitted to hospital gives 
rise to the danger of cross-infection by antibiotic-resistant organisms. Shortly before the trial reported here was started there was an outbreak of staphylococcal cross-infection, which made it necessary to withhold conventional antibiotic treatment in chronic bronchitic patients with acute exacerbations. These patients seemed to respond as rapidly as patients receiving antibiotics. With a disease so variable as chronic bronchitis the value of a particular treatment is difficult to assess, and therefore a formal double-blind trial for sequential analysis was planned and is reported here. The comparison was between the use of ampicillin, a broad-spectrum antibiotic, and no antibiotic.

\section{Methods}

\section{Selection of Patients}

Patients admitted to hospital for acute exacerbations of chronic bronchitis were accepted to the trial if they gave at least a three-year history of productive cough for more than three months in the year, and a history of at least two illnesses with increased sputum during that time. Patients with the following conditions were not accepted: severe cardiac failure unrelated to their chest disease ; carcinoma of the lung ; lung abscess ; long-standing bronchiectasis ; evidence of disseminated infection or septicaemia ; active tuberculosis ; allergy to penicillin. Also patients on adrenal corticoid treatment were not accepted. Cases of "cor pulmonale" were accepted. Previous antibiotic treatment, apart from a history of allergy, was ignored.

\section{Grading and Pairing}

Patients were graded according to the clinical evidence of bacterial infection. Those who showed two or more of the following were placed into the more severe grade I: (a) fever of over $99.5^{\circ} \mathrm{F}$. $\left(37.5^{\circ} \mathrm{C}\right.$.), (b) pulmonary consolidation, and (c) purulent sputum. The rest were placed in the less severe grade II.

Patients were paired and given a trial number. To be paired together two patients had to be (a) admitted within two weeks of each other, $(b)$ within 15 years of the same age, $(c)$ of the same grade (I or II), and (d) of the same sex. When there were alternative patients available for pairing at any one time the closest match was used.

\section{Treatment}

All patients were given similar treatment, apart from the capsules of antibiotic or placebo. This treatment included bed rest only if the patients were unable to get out of bed. Bronchodilator drugs were given orally and by aerosol. Cardiac and respiratory failure were treated with digitalis, diuretics, oxygen, and respiratory stimulants when necessary. Postural coughing and deep-breathing exercises were performed three or four times a day, and when they tolerated it the patients were encouraged to sleep with the foot of the bed raised and without pillows.

All patients received capsules of identical appearance which contained either ampicillin or an inert sugar. Boxes containing a week's supply of capsules were prepared by the hospital pharmacist; each box had a number corresponding to that allocated to the patient when admitted to the trial. The statistician had arranged with the pharmacist in advance which member of each pair was to receive ampicillin and which placebo. Neither the ward staff nor the assessing doctors had access to this information until the trial had been completed. The capsules were administered so that the patients on ampicillin received $1 \mathrm{~g}$. six-hourly for three days and $0.5 \mathrm{~g}$. six-hourly for four days.

\section{Assessment}

Data to be used for assessing which member of each pair did better were recorded on a form separate from the hospital notes.

On admission the clinical findings, the appearance and volume of the sputum, the $x$-ray findings, differential whitecell count, and sedimentation rate were recorded. The ventilatory function was measured by means of a Wright peak flow meter (Wright and McKerrow, 1959), and a specimen of sputum was sent for culture. The following were recorded daily: (1) four-hourly temperature, pulse, and respiration rate ; (2) daily sputum volume and appearance ; and (3) changes in clinical signs. Repeat peak flow recordings were done by the same observer every other day. Sputum was sent for culture on the fifth and seventh days.

The assessments of which of each pair responded more satisfactorily to treatment were not made until all the information on both patients could be assembled. The assessments were made at day 7 , when the course of capsules ended; again on the day of discharge ; and, finally, when followed up between 6 and 18 months after discharge.

\section{Withdrawals}

Any patient who deteriorated clinically after admission or who failed to improve after three days was regarded as a treatment failure, compared with his pair, and given any treatment necessary. If deterioration was due to allergy to penicillin or increasing bronchospasm requiring corticoid therapy he was not regarded as a treatment failure but was replaced if possible by the next suitable patient. Patients for whom suitably matched pairs could not be found in two weeks were withdrawn from the trial.

\section{Statistical Analysis}

Using only the data recorded on the forms during the first seven days, two of us made a decision on which member of each pair responded better to treatment. Assessments were also made at the end of the hospital stay and at the end of the follow-up period. These results were entered in the sequential analysis diagram prepared by the statistician (see Chart). In this diagram the limits are defined by the usual probability limits-namely, that a result would only be considered significant if its chance probability was less than $1: 20(P<0.05)$. The other limits of the diagram were defined as follows: for a result to be of clinical value benefit must be manifest in seven cases for every three in which the treatment is unsuccessful $\left(\theta_{1}=0.7 . \theta_{0}=0.3\right)$.

Conventional statistical methods were used for the analysis of single criteria of response and the importance of such factors as the presence of pathogenic organisms on admission. $\chi^{2}$ test was applied when the numbers were sufficient; in other instances the exact probability test was used. Again, the criterion of significance was a chance probability of less than $1: 20(\mathrm{P}<0.05)$.

\section{Supplementary Investigation}

The mortality and the length of hospital stay of the patients in the trial were compared with those of patients in three other medical units. One (A) was a general medical ward in a teaching hospital which carries a heavy load of acute emergencies; the second (B) was a general medical ward in the same nonteaching hospital as the trial patients; and the third (C) was in a hospital used only for chest diseases.

Matching pairs, with the trial patients as propositi, were drawn from the hospital records of each of the three units-A, $B$, and $C$. All the patients were admitted for exacerbations of 
bronchitis, and were matched for sex, age within five years, and date of admission within one month.

It was not possible to obtain patients to match all 56 propositi from each of the three units, but 41 were matched for unit $A$, 44 for unit B, and 55 for unit C. Only two facts were extracted from the notes of these patients: whether they survived the hospital admission, and, if they survived, the length of hospital stay.

\section{Results}

The trial was started in February 1963, when an emergency ward was opened for the care of acute respiratory illness. Unfortunately an insufficient number of patients were admitted to complete the trial before that winter ended. The trial was continued in the winter of $1963-4$, but fewer suitable patients were available for the trial, partly because of the milder winter and partly because hospital rebuilding restricted the number of beds available (see Table I).

TABLE I.-Patients Admitted to the Trial

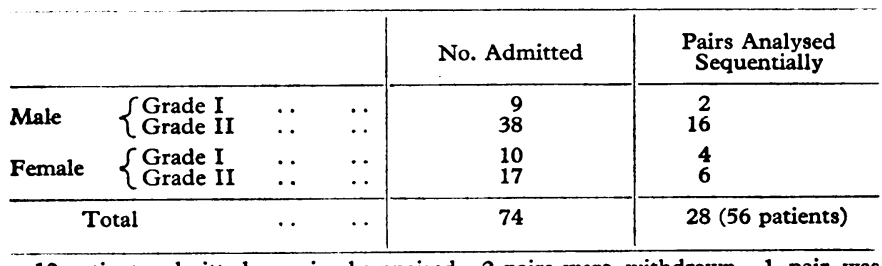

12 patients admitted remained unpaired. 2 pairs were withdrawn. 1 pair was mismatched for age. (This pair was included in the non-sequential analyses).

Seventy-four patients were admitted to the trial, but only 28 pairs ( 56 patients) were included in the sequential analysis. Twelve of the remaining 18 were not included because patients suitable for pairing were not admitted within two weeks. The remaining six were started as pairs but withdrawn. One pair had been mismatched for age ; one of the patients in the second pair developed severe bronchospasm and had to be given cortical steroids; and one patient in the third pair developed mania on the third day of ampicillin treatment. The 28 matched pairs and the pair mismatched for age were included in the non-sequential analyses.

\section{Toxicity}

Apart from the mania mentioned above only one patient was withdrawn because of symptoms which could possibly be attributed to the ampicillin. This patient developed acute diarrhoea on the second day of treatment and refused further treatment. Minor abdominal discomfort with looseness of stools was mentioned by several other patients but it did not prevent the completion of the course of treatment. Drug rashes were not noted during the seven days of treatment.

\section{Sequential Analysis}

The first time progress at the end of the seven days of treatment was assessed the sequential graph crossed the boundary in favour of treatment with ampicillin after the 21st pair. But the assessors (O.L.W. and P.C.E.) were aware that, in deciding which member of each pair responded better, they had been influenced by the bacteriological findings. The rapid disappearance of pathogens from the sputum was sometimes the main factor determining the decision in favour of treatment with ampicillin. After an interval of several weeks the assessment was repeated without using the bacteriological findings, and the graph failed to cross any boundary. This result was confirmed by an independent assessor who did not have the bacteriological findings (see Chart).
Assessment of the pairs at the end of the stay in hospital and at the end of the follow-up showed even less difference between treated and untreated cases. The trial was not continued long enough for any of the boundaries to be crossed.

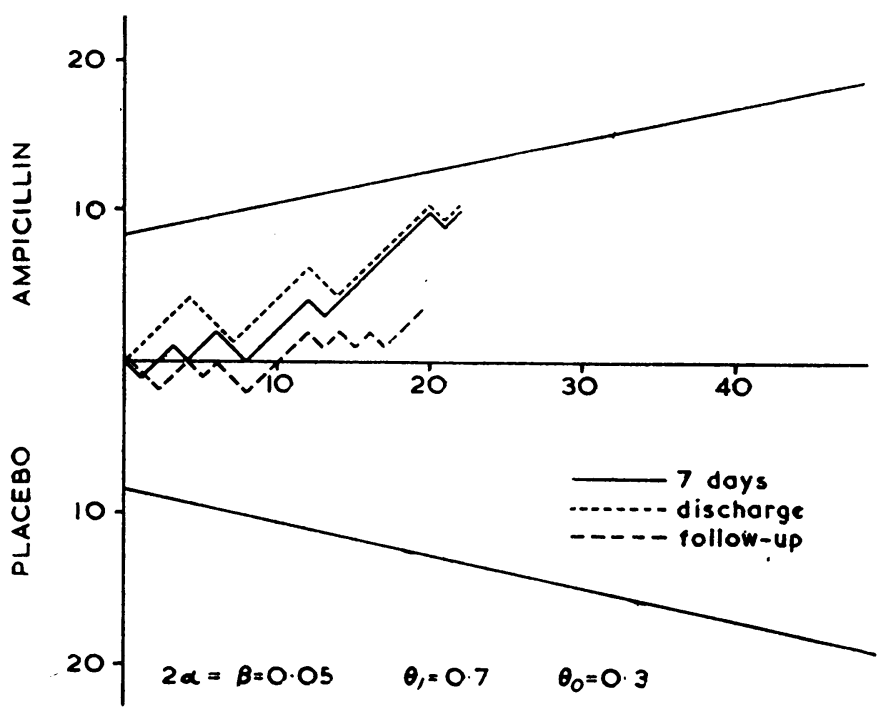

Part of the sequential analysis diagram showing the trace made by plotting the results of the comparisons made at seven days, at discharge, and at follow-up. If both the patients in a pair do equally well or badly this result is not plotted. The end limits of the diagram (not shown in the figure) giving the boundaries for " no significant difference between treatments "run from 75 pairs on the centre line to 104 pairs for the upper and lower boundaries.

\section{Other Analyses}

On admission to the trial the two groups of patients (treated and untreated) were comparable for age, sex, and sputum appearance (see Table II). The control group had significantly better ventilatory capacity on admission than the treated patients, but had more sputum. More specimens of sputum from the control group contained $H$. influenzae but fewer pneumococci than the ampicillin group; these differences were not statistically significant.

Deaths.-Five patients in the control group died in spite of changing to conventional antibiotic treatment when their condition deteriorated or failed to improve (Table III). Only one patient in the ampicillin group died. Such a difference could occur with a probability of $1: 5$ and is not statistically significant. The causes of death are shown in Table IV.

Relapses in hospital were defined as occasions on which it was thought advisable to initiate additional antibiotic treatment because of persistent fever with purulent sputum either during

TABLE II.-Characteristics of Patients on Admission

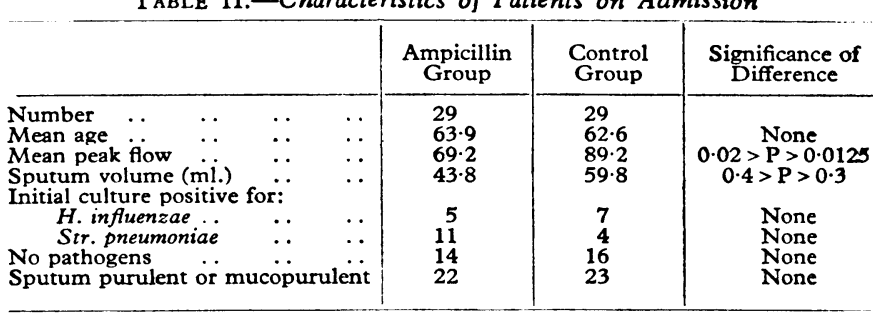

TABLE III.-Mortality and Relapses

\begin{tabular}{|c|c|c|c|c|}
\hline & & $\underset{\text { Group }}{\text { Ampicillin }}$ & $\begin{array}{l}\text { Control } \\
\text { Group }\end{array}$ & Significance \\
\hline \multirow{2}{*}{$\begin{array}{l}\text { Deaths in hospital } \\
\text { Deaths after discharge } \quad \ldots \\
\text { No. of patients with: } \\
\text { Relapses in hospital ... } \\
\text { Relapses after discharge }\end{array}$} & $\because$ & $\begin{array}{l}1 \\
6\end{array}$ & $\begin{array}{l}5 \\
4\end{array}$ & $\begin{array}{c}P=0.2 \text { (None) } \\
\text { None }\end{array}$ \\
\hline & $\because$. & $\begin{array}{r}5 \\
16\end{array}$ & $\begin{array}{l}14 \\
16\end{array}$ & $\begin{array}{c}0.05>P>0.00 \\
\text { None }\end{array}$ \\
\hline
\end{tabular}


or after the first seven days in hospital. Such episodes occurred significantly more often in the control group. After discharge there was an equal incidence of relapses requiring bed rest at home or admission to hospital (Table III).

Other Evidence of Improvement.-Length of stay in hospital, increase in peak flow rate, fall in sputum volume, and elimination of pathogens from the sputum at the time of discharge were not significantly different in the two groups (see Table V). Patients receiving ampicillin could be distinguished from the control patients by a greater tendency for purulent sputum to become mucoid and grow secondary invaders such as yeasts and coliforms during the seven days of treatment. These two changes were not necessarily accompanied by any clinical evidence of improvement but might indicate to an observer which patient in the pair was receiving ampicillin.

\begin{tabular}{c|c|c|c} 
& TABLE IV.-Causes of Death \\
\hline $\begin{array}{c}\text { Treatment } \\
\text { Group }\end{array}$ & $\begin{array}{c}\text { Length of Stay } \\
\text { Before Death }\end{array}$ & \multicolumn{1}{c}{ Cause } \\
\hline $\begin{array}{c}\text { Ampicillin } \\
\text { Control }\end{array}$ & $\begin{array}{r}9 \text { days } \\
7 \text { days } \\
23 \text { days }\end{array}$ & $\begin{array}{l}\text { Haematemesis and respiratory failure } \\
\text { Pulmonary artery thrombosis } \\
\text { Myocardial infarction (symptomless carcinoma of } \\
\text { stomach) } \\
\text { Respiratory failure } \\
\text { Respiratory failure with bronchospasm. (No } \\
\text { pneumonia at necropsy) } \\
\text { Respiratory failure with bronchospasm. (Minimal } \\
\text { pneumonia at necropsy) }\end{array}$ \\
\hline
\end{tabular}

\begin{tabular}{|c|c|c|c|}
\hline Criterion & Ampicillin & Control & Significance \\
\hline 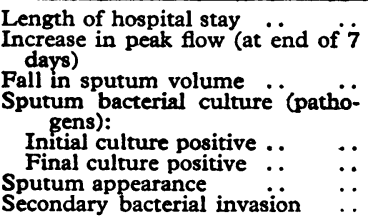 & $\begin{array}{l}18.3 \text { days } \\
51.5 \mathrm{ml} \\
9.6 \mathrm{ml} . / \text { day } \\
15 \\
8 \\
\text { Improved } \\
23 \text { cases }\end{array}$ & 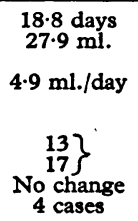 & $\begin{array}{c}\text { None } \\
0.1>\mathrm{P}>0.05 \\
\text { (Not significant) } \\
\text { Not significant } \\
\text { - } \\
\text { Not significant } \\
\mathbf{P}<0.02 \\
\text { Highly significant }\end{array}$ \\
\hline
\end{tabular}

\section{Investigation of Other Features}

The patients were sorted according to characteristics which might be thought to influence prognosis. It was found (Table VI) that age had no significant effect. Definite evidence of infection (grade I patients) was associated with a greater frequency of relapses. Poor ventilatory function on admission was associated with a longer stay in hospital. Neither the volume nor the purulence of the sputum during the first 24 hours was of prognostic significance.

Table VI.-Clinical Features on Admission and Prognosis

\begin{tabular}{|c|c|c|c|}
\hline \multirow[b]{2}{*}{ Feature } & \multirow{2}{*}{$\begin{array}{l}\text { No. of } \\
\text { Patients }\end{array}$} & \multicolumn{2}{|c|}{ Effect on Prognosis } \\
\hline & & $\begin{array}{l}\text { Placebo } \\
\text { Treatment }\end{array}$ & $\begin{array}{l}\text { Ampicillin } \\
\text { Treatment }\end{array}$ \\
\hline Age (over 64 cf. 64 and under) & 30 cf. 28 & $\begin{array}{l}\text { More deaths. } \\
\text { Longer stay in } \\
\text { hospital }\end{array}$ & $\begin{array}{l}\text { No different } \\
\text { from placebo }\end{array}$ \\
\hline Clinical grade : I cf. II & $12 \mathrm{cf} .46$ & $\begin{array}{l}\text { More relapses } \\
\text { in hospizal }\end{array}$ & No difference \\
\hline Peak flow: over cf. ander 75 1./min. & 26 cf. 32 & $\begin{array}{l}\text { Longer stay in } \\
\text { hospital }\end{array}$ & $\begin{array}{l}\text { Longer stay in } \\
\text { hospital }\end{array}$ \\
\hline $\begin{array}{l}\text { Sputum volume: over cf. under } 35 \\
\text { ml./day }\end{array}$ & $28 \mathrm{cf} .30$ & No effect & No effect \\
\hline $\begin{array}{l}\text { Sputum appearance: purulent } \\
\text { mucopurulent or mucoid.. }\end{array}$ & 13 cf. 45 & No effect & No effect \\
\hline
\end{tabular}

Statistically significant effects are in italic.

When the patients with $H$. influenzae in the initial sputum were compared with the other patients (Table VII) there was a difference between those receiving ampicillin and those receiving placebo. The control patients with $H$. influenzae had significantly more relapses in hospital and stayed in longer than the controls without $H$. influenzae. The ampicillin-treated patients with $H$. influenzae had a significantly shorter stay in hospital but the same frequency of relapses as the ampicillin-treated patients without $H$. influenzae. The presence of this organism in the initial sputum had no apparent influence on mortality or on the clinical course after discharge from hospital.

TABLE VII.-Laboratory Features on Admission and Prognosis

\begin{tabular}{|c|c|c|c|}
\hline \multirow[b]{2}{*}{ Feature } & \multirow{2}{*}{$\begin{array}{l}\text { No. of } \\
\text { Patients }\end{array}$} & \multicolumn{2}{|c|}{ Effect on Prognosis } \\
\hline & & $\begin{array}{l}\text { Placebo } \\
\text { Treatment }\end{array}$ & $\begin{array}{l}\text { Ampicillin } \\
\text { Treatment }\end{array}$ \\
\hline 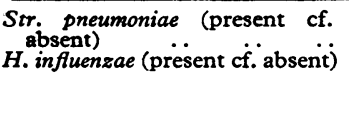 & $\begin{array}{l}15 \mathrm{cf} .43 \\
11 \mathrm{cf} .47\end{array}$ & $\begin{array}{l}\text { No effect } \\
\text { More relapses in } \\
\text { hospital } \\
\text { Longer stay in } \\
\text { hospital }\end{array}$ & $\begin{array}{l}\text { No effect } \\
\text { Shorter stay in } \\
\text { hospital }\end{array}$ \\
\hline
\end{tabular}

tatistically significant effects are in italic.

The isolation of Str. pneumoniae from the sputum on admission and the presence of secondary invaders during the course of treatment had no apparent influence on the prognosis.

\section{Comparison with Other Medical Units}

The average length of stay of equivalent patients in the three other units during the same period is shown in Table VIII. Patients in units A and B averaged about four days longer than their matched pairs in the trial. Unit $C$ did not admit general medical emergencies, and was expected to take a higher proportion of patients with prolonged severe chest disease. Patients stayed on the average nearly twice as long in this unit. The death rates between the four units did not differ significantly.

TABLB VIII.-Comparison with Matched Patients in other Units

\begin{tabular}{c|c|c|c}
\hline Unit & $\begin{array}{c}\text { No. of Patients } \\
\text { Matched }\end{array}$ & $\begin{array}{c}\text { No. of } \\
\text { Deaths }\end{array}$ & $\begin{array}{c}\text { Length of Stay in } \\
\text { Days (Survivors } \\
\text { only) }\end{array}$ \\
\hline A & 41 & $4(4)^{*}$ & $22 \cdot 6(18 \cdot 5)^{*}$ \\
B & 44 & $5(6)^{*}$ & $20.4(16 \cdot 1) \dagger$ \\
& 55 & $1(6)^{*}$ & $34.9(18 \cdot 1) t$
\end{tabular}

The figures in parentheses are those for the propositi in the trial series who were paired successfully.

Difference not statistically significant.

$t$ Difference significant (when distributed about the combined mean the $x^{2}$

\section{Discussion}

This trial was terminated prematurely, for reasons unrelated to its results, before a statistically significant answer in the sequential analysis had been obtained. The patients in the trial were elderly and ill. Their mean age was 63 years, one-quarter were over 70 and two were over 80 . Several patients had such small ventilatory capacity that they were unable to record a reading on the peak flow meter. The mortality rate of 6 deaths in 58 patients is comparable to that in two other acute medical units at the same time for similar cases. In only three of the six deaths was there any evidence that infection contributed to the cause of death.

Assessments made after seven days, when the observers were not biased by the knowledge of the bacteriological findings in the sputum, did no more than suggest that ampicillin gave some benefit compared with a placebo. Assessments made at the time of discharge and after follow-up showed even less evidence of benefit. This failure to show a statistically significant benefit after 28 pairs of patients had been studied in a sequential trial indicates the relative lack of importance of ampicillin in the hospital treatment of exacerbations of chronic bronchitis.

Ampicillin has been shown (Rolinson and Stevens, 1961) to be bactericidal against Str. pneumoniae and $H$. influenzae, and should have reached adequate tissue levels (May and Delves, 1964 ) in the high doses used. The bacteriological findings in this trial confirm that the drug was effective in removing these 
two pathogens from the sputum during treatment, though they often reappeared before the patient left hospital.

However, this alteration in the flora of the bronchi appears to have conferred little additional benefit on patients already receiving routine ward treatment. This routine, with breathing exercises, postural drainage, bronchodilator sprays, and early ambulation, was applied with as much enthusiasm and frequency as was humanly possible. There was an atmosphere of active treatment for an of ten neglected illness which must have contributed psychologically and allowed the earlier discharge of patients.

Our results indicate that ampicillin reduces the frequency of early relapses even if it does not affect the ultimate prognosis of the acute illness. The frequency of relapses seemed to be reduced only in those patients with $H$. influenzae in their sputum on admission. Unfortunately this test takes time, and is especially unreliable when the patient has received antibiotics before admission. If treatment is to be started straightaway a different method of selecting which patients need antibiotic treatment is needed.

Antibiotic therapy is not without its hazards, both to the patient and to other patients around him in the hospital environment. Broad-spectrum antibiotics are particularly apt to encourage cross-colonization by "hospital" antibiotic-resistant bacteria.

New methods are needed so that the patient who will really benefit from antibiotic therapy can be identified as soon as he reaches the ward. The rest of the bronchitic patients should not receive antibiotics while in hospital.

\section{Summary}

The value of ampicillin in the hospital treatment of exacerbations of chronic bronchitis has been assessed in a double-blind trial.

Twenty-eight pairs of patients were included in a sequential trial in which all patients were treated intensively with broncho- dilator drugs and physiotherapy. One member of each pair received bacteriologically effective doses of ampicillin for seven days, while the other member of the pair received placebo.

Sequential analysis of the results showed no conclusive evidence that the ampicillin was beneficial.

Ampicillin did not shorten the length of the patients' stay in hospital. In those patients whose sputum cultured Haemophilus influenzae on admission there was a reduction in the frequency of relapses while the patient was still in hospital.

There was no evidence that any such improvement caused by the ampicillin persisted after the patient was discharged from hospital.

We are grateful to Dr. J. A. Fisher, who acted as the independent observer. We are indebted to the Northern Ireland Hospitals Authority for making the beds available which made this trial possible, and for funds granted through their Medical Education and Research Committee. The trial could not have been run without the active co-operation of the staff of the Belfast City Hospital, and in particular Ward Sisters Harrison and McCully, Miss Kelso, of the Physiotherapy Department, and Mr. Coulter, chief pharmacist. Statistical advice was obtained from Dr. J. D. Merrett, of the Department of Medical Statistics. Dr. O. P. W. Robinson kindly arranged for the supply of all the ampicillin and placebo capsules by Beecham Pharmaceuticals Ltd. free of charge.

\section{REFERENCES}

Crofton, J. (1963). Prescrib. 7., 3, 61.

Elmes, P. C., Knox, K., and Fletcher, C. M. (1953). Lancet, 2, 903. - and White, J. C. (1953). Thorax, 8, 295. Garrod, L. P., Scadding, J. G., and Watson, G. I. (1963). Brit. med. \}., $2,1453$.

Johnston, R. N. (1963). In Symposium on Chronic Respiratory Disorders, p. 76. Royal College of Physicians of Edinburgh.

May, J. R. (1958). In Recent Trends in Chronic Bronchitis, edited by N. C. Oswald, p. 88. Lloyd-Luke, London.

Reid, Lynne (1958). In Recent Trends in Chronic Bronchitis, edited by , Lynne (1958). In Recent Trends in Chron

N. C. Oswald, p. 26. Lloyd-Luke, London.
Rolinson, G. N., and Stevens, S. (1961). Brit. med. F., 2, 191.

Rolinson, G. N., and Stevens, S. (1961). Brit. med. 7., $2,191$.
Wright, B M., and McKerrow, C. B. (1959). Ibid., 2, 1041.

\title{
Surgical Treatment of Bronchiectasis : Ten-year Survey
}

\author{
JOHN BORRIE,* M.B.E., CH.M., F.R.C.s., F.R.A.C.S. ; IVAN LICHTER,* F.R.C.S., F.R.A.C.S.
}

Brit. med. F., 1965, 2, 908-912

In the decade 1952-62 125 patients were operated on for bronchiectasis in the Southern Metropolitan Thoracic Surgical Unit, Dunedin. In 91 of these the resection was unilateral and in 34 bilateral. Two patients with unilateral disease required a second operat:on for removal of a lung segment that had become bronchiectatic after the first operation. Four of those with bilateral disease required a subsequent segmental resection. In the period analysed, therefore, 165 operations for bronchiectasis were performed on 125 patients, as follows:

$$
\begin{aligned}
& \text { Unilateral bronchiectasis } \ldots\left\{\begin{aligned}
91 & \text { resections } \\
2 & \text { subsequent resections }
\end{aligned}\right. \\
& \text { Bilateral bronchiectasis } \ldots\left\{\begin{aligned}
68 & \text { resections } \\
4 & \text { subsequent resections }
\end{aligned}\right.
\end{aligned}
$$

All these patients were referred from the Chest Clinic, Dunedin Hospital, or Regional Chest Clinics, Otago and Southland, because of failure of medical treatment.

There were 75 females and 50 males, a proportion of 1.5 to 1 . This supports the experience of Ginsberg et al. (1955). Other reported series have shown a different sex distribution (Lindskog and Hubbell, 1955). The unilateral group comprised 53 females and 38 males, and the bilateral group 22 females and 12 males. The two groups are analysed separately.

\section{Unilateral Bronchiectasis}

Age Distribution.-The age distribution at the time of onset of symptoms and at operation is given in Table I. These figures show that in two-thirds of the patients the onset of symptoms occurred in the first decade of life. The age distribution at operat on, however, showed a different pattern Thus over a third of the patients were operated upon in the second decade of $1 \mathrm{fe}$. It was felt that convalescence, in the

* From the Department of Thoracic Surgery, Dunedin and Wakari
Hospitals, and the Department of Surgery, University of Otago Hospitals, and the Department of Surg
Medical School, Dunedin. New Zealand. 